NBER WORXING PAPER SERIES

\title{
CAN INTER-INDUSTRY WAGE DIFFERENTIALS JUSTIFY STRATEGIC TRADE POLICY?
}

Lawrence F. Katz

Lawrence H. Sumers

Working Paper No. 2739

\author{
NATIONAL BUREAU OF ECONOMIC RESEARCH \\ 1050 Massachusetts Avenue \\ Cambridge, MA 02138 \\ October 1988
}

We thank William Dickens and Alan Krueger for many helpful discussions. We are grateful to Robert Stern for generously providing us with trade flow data, to Richard Baldwin for providing us with data on Airbus, and to Joe Cooper, David Cutler, and Daniel Kessler for expert research assistance. An analysis of labor rents and trade policies paralleling ours in many respects is presented in Dickens and Lang (1988). Our analysis differs in contrasting the relative importance of labor market and product market imperfections, focusing on the manufacturing sector, and making international comparisons of wages and trade flows. This research is part of the NBER's research programs in International Studies and in Labor Studies. Any opinions expressed are those of the authors not those of the National Bureau of Economic Research. 
NBER Working Paper \#2739

October 1988

\section{CAN INTER-INDUSTRY WAGE DIFFERENTIALS \\ JUSTIFY STRATEGIC TRADE POLICIES}

\section{ABSTRACT}

This paper examines the relationship between labor market imperfections and trade policies. The available evidence suggests that pervasive industry wage differentials of up to 20 percent remain even after controlling for differences in observed measures of workers' skill and the effects of unions. Theoretical analysis indicates that given non-competitive wage differentials of this magnitude policies directed at encouraging employment in high-wage sectors could significantly enhance allocative efficiency. For the United states and other developed countries, such policies are more likely to involve export promotion than import substitution. Increased international trade flows (at least through 1984) have been associated with increased employment in high-wage U.S. manufacturing industries relative to low-wage U.S. manufacturing industries.

Lawrence F. Katz Department of Economics Harvard University Cambridge, MA 02138
Lawrence H. Summers Department of Economics Harvard University Cambridge, MA 02138 


\section{Introduction}

Industrial policies have been a major source of economic and political debate in the United states and other nations in recent years. Advocates of industrial policies assert that since all public policies inevitably influence the composition of output and some industries are "better" for a national economy than others, it is appropriate for governments to manage their influence on the economy to promote goals like growth and competitiveness. Industrial policy advocates often cite Japan as an example of a nation that has benefitted from sound industrial policies. Critics of industrial policy have generally cited standard economic arguments against such policies, suggesting that in competitive or nearly competitive markets, there are no gains to be had from altering the composition of output.

In tandem with political debates over industrial policy, a burgeoning academic literature on strategic trade policy, initiated by Brander and Spencer $(1983,1984)$ and surveyed in Krugman (1986), has examined policy measures that can shift monopoly rents from one nation to another when product markets are imperfectly competitive. A central focus in this literature has been on imperfections in product markets, especially markets with large learning curve effects. While this literature has yielded intriguing counterexamples to some widely believed propositions, we believe that its emphasis on product market imperfections as the potential 
rationale for industrial policies is somewhat misplaced. ${ }^{1}$

We suspect that deviations from competitive labor markets which give rise to significant inter-industry wage differentials are at least equally important for industrial policy as are product market imperfections. Industrial policy advocates like Robert Reich and Lester Thurow, who encourage subsidies for "high value added production", appear to be referring not to especially profitable industries, but to industries that pay high wages. The international pervasiveness of subsidies to steel industries is probably more easily understood on the basis of their high wage jobs than on the basis of the profits earned by steel companies.

The observation that rents accruing to labor are much more significant than monopoly rents received by firms is a very general one. For the American non-financial corporate sector in 1987 , employee compensation represented 82 percent of value added while operating profits represented only 18 percent, with the bulk of the latter figure being the return to capital rather than monopoly rents. It follows that the labor rents associated with industry wage differentials of even 10 percent bulk very large when compared with plausible estimates of firms' monopoly rents. ${ }^{2}$

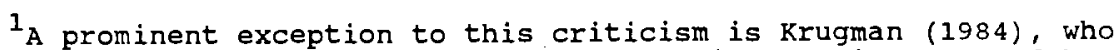
emphasizes the potential importance of wage differentials caused by unions.

2 The presumption that labor rents are much greater than rents received by firms does not necessarily mean that product market imperfections are a minor source of rents. A large fraction of the rents earned by workers may arise from the ability of both union and nonunion labor to share in product market rents. For example, Salinger (1984) presents evidence indicating that union labor captures most of the monopoly rents in heavily unionized 
This paper explores both theoretically and empirically the implications of labor market imperfections for trade policies, focusing on the situation of the United States in the 1980s. We begin in section II by demonstrating that, contrary to competitive labor market theories, there are substantial differences between industries in the compensation received by workers with similar characteristics working under apparently similar conditions. The industrial wage structure is remarkably stable across time and space. While unions are a partial source of these wage differentials, wage differentials are large for non-union workers and in settings like the American South, where: union threats are not very important. The differentials appear to arise from the differential importance of motivating, retaining, and recruiting workers as suggested by the efficiency wage theories surveyed in Katz (1986) and from rent-sharing considerations.

Section III considers theoretically the implications of noncompetitive wage differentials for trade and industrial policies. We find that inter-industry wage differences provide a rationale for policies quite similar to those that have been advanced by industrial policy advocates. While it is difficult to justify subsidizing industries that achieve high value added per worker by relying on abnormally skilled workers or by using a great deal of capital or other inputs, there is a rationale for subsidizing industries that have high value added per worker because of noncompetitive wage differentials. If firms hire labor to the point

industries. 
where its marginal product equals the wage, the marginal

productivity of an additional worker is greater in sectors paying premium wages than in competitive wage sectors. In this case, policy measures that expand employment in high-wage sectors may be desirable. Of course, the basic thrust of this theoretical argument is not new. The role of factor market distortions in the design of optimal trade policies has played a prominent role in trade theory at least since the work of Hagen (1958) and of Bhagwati and Ramaswami (1963). Furthermore, both stylized calculations and consideration of actual examples suggest that these effects may well be quantitatively important.

Section IV combines data on industry wage premiums with data on trade flows to assess the importance of wage differentials for trade policies. We reach three primary conclusions. First, wage differentials cause the United States to reap extra gains from trade, at least within the manufacturing sector. Us manufacturing exports come disproportionately from industries that pay premium wages, while manufacturing imports generally come from low-wage sectors. Second, exporting high-wage goods while importing lowerwage goods is a characteristic common to other developed countries. Third, despite concerns about undesirable changes in the structure of the US economy, it does not appear (at least through 1984) that changing trade patterns have disproportionately hurt the high-wage portion of the US manufacturing sector. Instead, increased import competition has had its greatest impact on employment in low-wage parts of the U.S. manufacturing sector. 
Section $\mathrm{V}$ concludes the paper by offering a tentative assessment of the implications of our results for actual trade industrial and tax policies. Our general view is that policies directed at reducing imports are likely to have extremely adverse impacts on economic welfare, whereas certain measures aimed at expanding employment in export sectors may increase welfare. Any economic case for activist policy must be tempered by a recognition that theoretically optimal policies are extremely unlikely to be implemented in practice.

\section{The Importance of Inter-Industry Wage Differentials}

Several recent studies have documented large and persistent wage differentials among industries, even after controlling for a wide variety of worker and job characteristics (Dickens and Katz, 1987a,b; Krueger and Summers, 1987, 1988; and Murphy and Topel, 1987). ${ }^{3}$ The pattern of these differentials is remarkably parallel in looking at data for different countries and time periods and suggests that workers in some sectors earn substantial rents. This section summarizes the available evidence on the inter-industry wage structure and discusses the consistency with the evidence of alternative models of wage determination. We conclude that competitive labor market explanations stressing unmeasured labor quality and compensating differentials do not provide a plausible

${ }^{3}$ This conclusion is hardly new. It was noted by Adam Smith, highlighted by sumner slichter (1950), and has been emphasized by institutionally- oriented labor economists for many years. 
explanation for a substantial component of inter-industry wage variations, even for non-union workers. Instead, industry wage differentials largely reflect firms' differing needs to use high wages to motivate, retain and recruit their workers.

\section{The Magnitude of Inter-Industry wage Differences}

We analyze industry wage differences in the United states using cross-sectional data on individuals from the 1984 Current population Surveys. All twelve CPS surveys from 1984 were combined to generate a sample large enough to accurately estimate wage differentials for detailed industry categories. 4 our sample consists of private sector, nonagricultural employees 16 years old or older. The earnings variable is usual weekly earnings divided by usual weekly hours. 5 The procedures utilized are described in krueger and Summers (1988). In particular, we normalize the estimated wage differentials as deviations from the (employment-weighted) mean differential.

The first column in Table 1 reports the proportionate difference in wages between the average worker in a two-digit census industry and the weighted average worker in all industries. The second column reports the normalized industry wage differences after controlling for education, age, occupation, gender, race, marital

${ }^{4}$ Although the CPS is partially a panel data set, only individuals in outgoing rotation groups are asked about earnings. Further, people exit the sample only once a year. Thus, all observations reflect unique individuals.

${ }^{5}$ We eliminated employees who reported earning less that $\$ 1.00$ an hour or greater than $\$ 250$ an hour. 
Table 1: Estimated Industry Log Wage Differentials -- Fu11 Year 1984 CPS $^{\text {a }}$

\begin{tabular}{|c|c|c|c|c|}
\hline Industry & $\begin{array}{l}\text { (1) } \\
\text { All } \\
\text { Without } \\
\text { Controls }\end{array}$ & $\begin{array}{l}\text { (2) } \\
\text { A:1 } \\
\text { With b } \\
\text { Controls }\end{array}$ & $\begin{array}{l}\text { (3) } \\
\text { All - Total } \\
\text { Compensation } \\
\text { With } \\
\text { Controls }\end{array}$ & $\begin{array}{l}\text { (4) } \\
\text { Nonunion } \\
\text { With } \\
\text { Controls }\end{array}$ \\
\hline Mining & .396 & .268 & .280 & .273 \\
\hline Construction & .163 & .113 & .100 & .068 \\
\hline Lumber & -.118 & -.030 & .007 & .007 \\
\hline Furniture & -.120 & -.035 & -.014 & .005 \\
\hline Stone, Clay \& Glass & .084 & .070 & .124 & .066 \\
\hline Primary Metals & .269 & .169 & .270 & .166 \\
\hline Fabricated Metals & .128 & .077 & .138 & .082 \\
\hline Machinery Excl. Elec. & .299 & .149 & .186 & .177 \\
\hline Electrical Machinery & .177 & .085 & .114 & .107 \\
\hline Transport Equipment & .375 & .211 & .288 & .194 \\
\hline Instruments & .247 & .110 & .139 & .158 \\
\hline Misc. Manufacturing & -.102 & -.062 & -.041 & -.015 \\
\hline Food & .039 & .052 & .105 & .041 \\
\hline Tobacco & .248 & .236 & .424 & .213 \\
\hline Textile & -.146 & -.002 & .010 & .048 \\
\hline Apparel & -.358 & -.153 & -.149 & -.111 \\
\hline Paper & .220 & .168 & .205 & .149 \\
\hline Printing & .055 & .033 & .037 & .034 \\
\hline Chemical & .343 & .192 & .237 & .223 \\
\hline Petroleum & .490 & .294 & .543 & .292 \\
\hline Rubber & .090 & .101 & .146 & .132 \\
\hline Leather & -.294 & -.134 & -.113 & -.090 \\
\hline Other Transport & .245 & .179 & .208 & .092 \\
\hline Communications & .385 & .250 & .373 & .215 \\
\hline
\end{tabular}


Table 1 (continued)

\begin{tabular}{|c|c|c|c|c|}
\hline Industry & $\begin{array}{l}\text { (1) } \\
\text { Al1 } \\
\text { Without } \\
\text { Controls }\end{array}$ & $\begin{array}{c}\text { (2) } \\
\text { All } \\
\text { With } \\
\text { Controls }\end{array}$ & $\begin{array}{l}\text { (3) } \\
\text { All - Total } \\
\text { Compensation } \\
\text { With } \\
\text { Controls }\end{array}$ & $\begin{array}{l}\text { (4) } \\
\text { Nonunion } \\
\text { With } \\
\text { Controls }\end{array}$ \\
\hline Public Utilities & .349 & 201 & .278 & .192 \\
\hline Wholesale Trade & .108 & .040 & .018 & .058 \\
\hline Eating and Drinking & -.605 & -.244 & -.274 & -.228 \\
\hline Other Retail Trade & -.267 & -.139 & -.169 & -.138 \\
\hline Banking & .098 & .048 & .077 & .066 \\
\hline Insurance & .101 & .049 & .053 & .069 \\
\hline Private Household & -.809 & -.339 & -.490 & -.312 \\
\hline Business Services & -.010 & -.015 & -.046 & .004 \\
\hline Repair Services & -.076 & -.085 & -.115 & -.053 \\
\hline Personal Services & -.384 & -.180 & -.219 & -.161 \\
\hline Entertainment & -.211 & -.130 & -.151 & -.144 \\
\hline Medical Services & -.152 & -.034 & -.030 & -.014 \\
\hline Hospitals & .096 & .060 & .064 & .077 \\
\hline Welfare Services & -.187 & -.203 & -.286 & -.207 \\
\hline Education Services & .078 & -.078 & -.099 & -.105 \\
\hline Professional Services & .271 & .091 & .052 & .105 \\
\hline Sample Size & 135595 & 135595 & 135595 & 106599 \\
\hline $\begin{array}{l}\text { Weighted adjusted } \\
\text { S.D. of differentials }\end{array}$ & .270 & .144 & .185 & 141 \\
\hline
\end{tabular}

${ }^{a}$ Standard errors are not reported to save space. In all cases, the standard errors are between .004 and .020 except for Tobacco which has standard errors which range from .039 to .049 .

b Controls include education and its square; six age dummies; eight occupation dummies; female dunny; race dumny; SMSA dumny; 3 region dumnies; full-time work dumny; full- and part-time student dummies; interactions of the female dumny with marriage, education, education squared, and the 6 age dumies; and a constant. Each column was estimated from a separte cross-sectional regression.

c Weights are employment shares for the entire sample (union and nonunion). 
status, SMSA, full-time work, student status, and allowing many of the coefficients to differ for males and females. Controlling for available worker characteristics has little impact on the rankings of different industries; the correlation of the industry wage differentials estimated with and without controls is 0.96 . This finding suggests that comparisons of average industry wages over time and across countries may be useful since it is unlikely that controls would change one's inferences about the relative rankings of industries in the wage structure.

The controls do substantially reduce the estimated interindustry dispersion of wages. The standard deviation of the estimated wage differentials falls from 27 percent without controls to 14 percent when controls are added. Almost all of this decline is attributable to holding occupation and sex constant. Industry affiliation has a large impact on relative wages even allowing for observed differences in occupation, human capital variables, and demographic background. Industry differentials range from a high of 29 percent above the mean in petroleum to 34 percent below the mean in private household services. Durable goods manufacturing, mining, and chemicals industries pay wages well above those for workers in retail trade and service industries, all else constant. Substantial wage differentials are also apparent within the traded-goods (manufacturing) sector.

One possibility is that these differentials largely serve to offset differences in nonwage compensation. One non-wage aspect of compensation which we can control for using our data is fringe 
benefits. Fringe benefits account for as much as 50 percent of compensation in some industries. To adjust for variation in fringes across industries, we multiplied our CPS hourly wage data for each worker in the sample by the ratio of total labor costs to wages in the corresponding industry. ${ }^{6}$ The third column of Table 1 presents estimates of industry wage differentials with the dependent variable adjusted to reflect both wage and nonwage compensation. ${ }^{7}$ The estimated standard deviation of industry differentials actually increases by more than one-fourth from 14.4 to 18.5 percent. Thus, the consideration of fringe benefits reinforces, rather than reduces, industry compensation differences.

Discussions of industry wage differences frequently emphasize the importance of unions in wage setting. The inclusion of union membership and union coverage dummy variables in the specification reported in the second column of Table 1 , however, has little impact on the estimated industry differentials. The standard deviation of the differentials falls from 14.4 to 13.9 percent. Since unions are likely to have different impacts on wages in industries with different product market structures and costs of strikes, a better approach is to assess the importance of industry differentials for a

${ }^{6}$ The industry labor cost and wage data are reported in the National Income and Product Accounts (NIPA) and were previously utilized in Krueger and Summers (1988).

${ }^{7}$ Since the NIPA and CPS industry classification schemes do not match exactly, caution should be taken in comparing the results in column (3). 
sample containing only nonunion workers. ${ }^{8}$ Column (4) of Table 1 presents these. The industry wage premia are quite substantial for nonunion workers. We also estimated differentials for the union workers in our sample and found the standard deviation of the differentials to be slightly larger for nonunion workers (14.1 to 13.3 percent). The correlation of the differentials for the union and nonunion samples is 0.80 . There appears to be little difference in the process generating industry relative wages in the union and nonunion sectors. Further evidence that unions are not the primary factor accounting for wage differentials comes from Krueger and Summers' (1988) finding that the wage structure in the southern part of the United States looks very similar to that in the rest of the country despite much lower rates of unionization.

\section{Reqularities in the Inter-Industry wage Structure}

Industry wage differences appear to be quite stable across time and space. Krueger and Summers (1987) examine evidence on the industry wage structure in the United States from 1900 to 1984 . They find that between 1900 and 1984 the correlation between relative wages in nine major industries is 0.62 and between 1970 and 1984 the correlation is 0.91 . Krueger and summers further document that the relative rankings of industry average wages in detailed manufacturing industries is also extremely stable over time. Figure

${ }^{8}$ The nonunion sample consists of workers not covered by collective bargaining agreements. The results are almost identical when the union membership is used as the criterion for excluding a worker from the nonunion sample. 


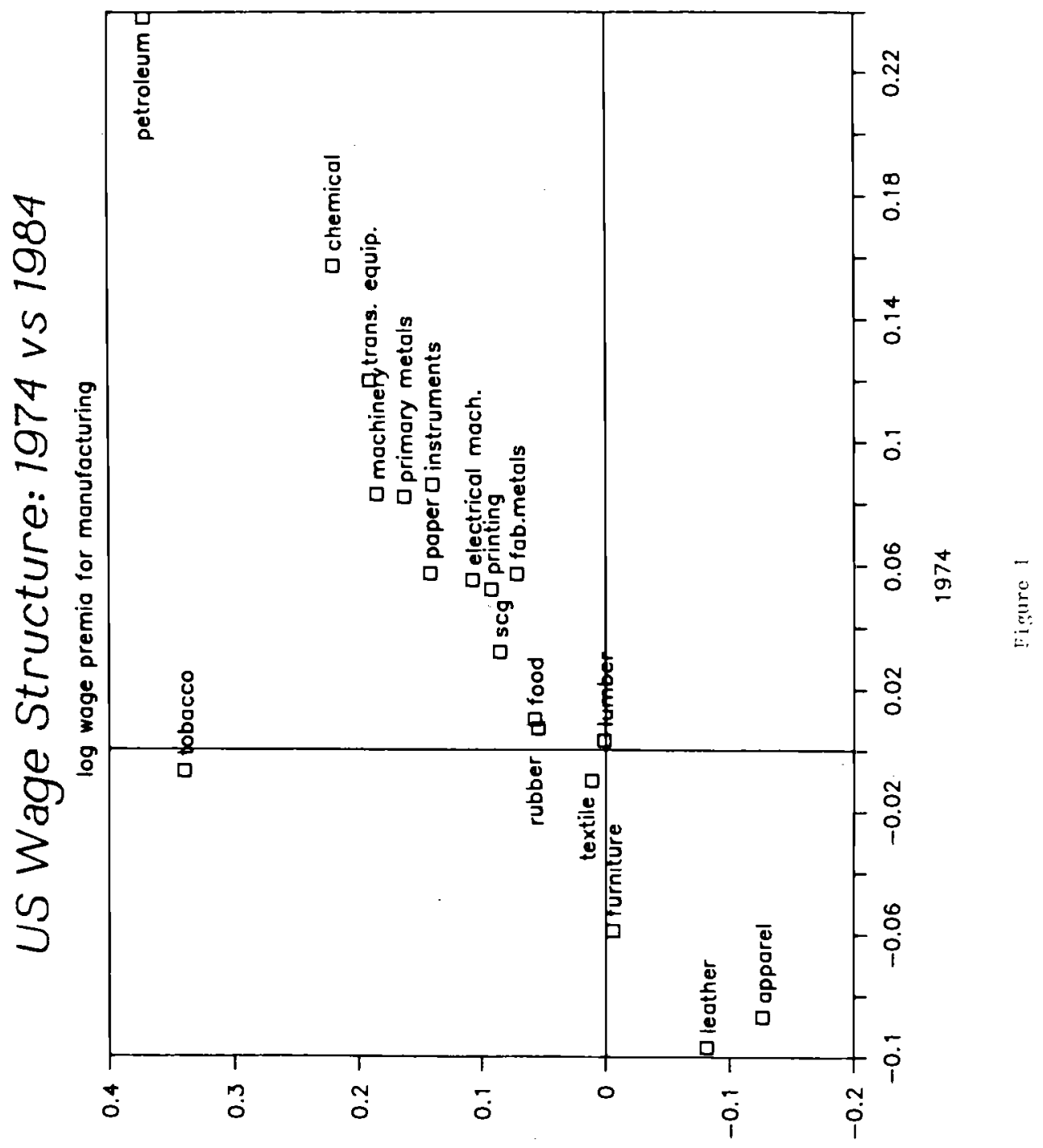

$+861$ 
1 plots industry wage differentials for twenty two-digit manufacturing industries estimated from the May 1974 CPS against analogous differentials estimated from the May 1984 CPS. ${ }^{9}$ Despite widespread concern about the impact of trade on affected industries, the figure illustrates that the industry wage structure in manufacturing has been very stable over the last decade. Freeman and Katz (1987) study the effects of import competition on wages in US manufacturing and find that a 10 percent decrease in industry revenues from increased import penetration reduces an industry's relative wage for production workers by only 0.5 percent. 10

Industry wage patterns are remarkably similar among countries with diverse labor market institutions. Table 2 presents evidence on the remarkable similarity of relative wages in manufacturing among 9 countries in 1982. The use of a single occupational group (operatives) allows us to control for skill mix differences across countries. The cross-country correlations of relative wages are quite high, typically between 0.6 and 0.9 . For example, the correlation between the relative wages of operatives in the U.S. and Japan is 0.95 . We illustrate this similarity in the wage structures of U.S. and Japan in Figure 2. Krueger and Summers (1987) also find strong positive correlations in relative average industry wages (1988).

${ }^{9}$ The estimates are taken from Table II of Krueger and summers

${ }^{10}$ In contrast, Murphy and Welch (1988) document that the earnings of "skilled" (college-educated) workers rose dramatically relative to those of less-educated workers from 1979 to 1985 . They provide some suggestive evidence that increased net imports in manufacturing may have played an important role in the widening of skill differentials. 


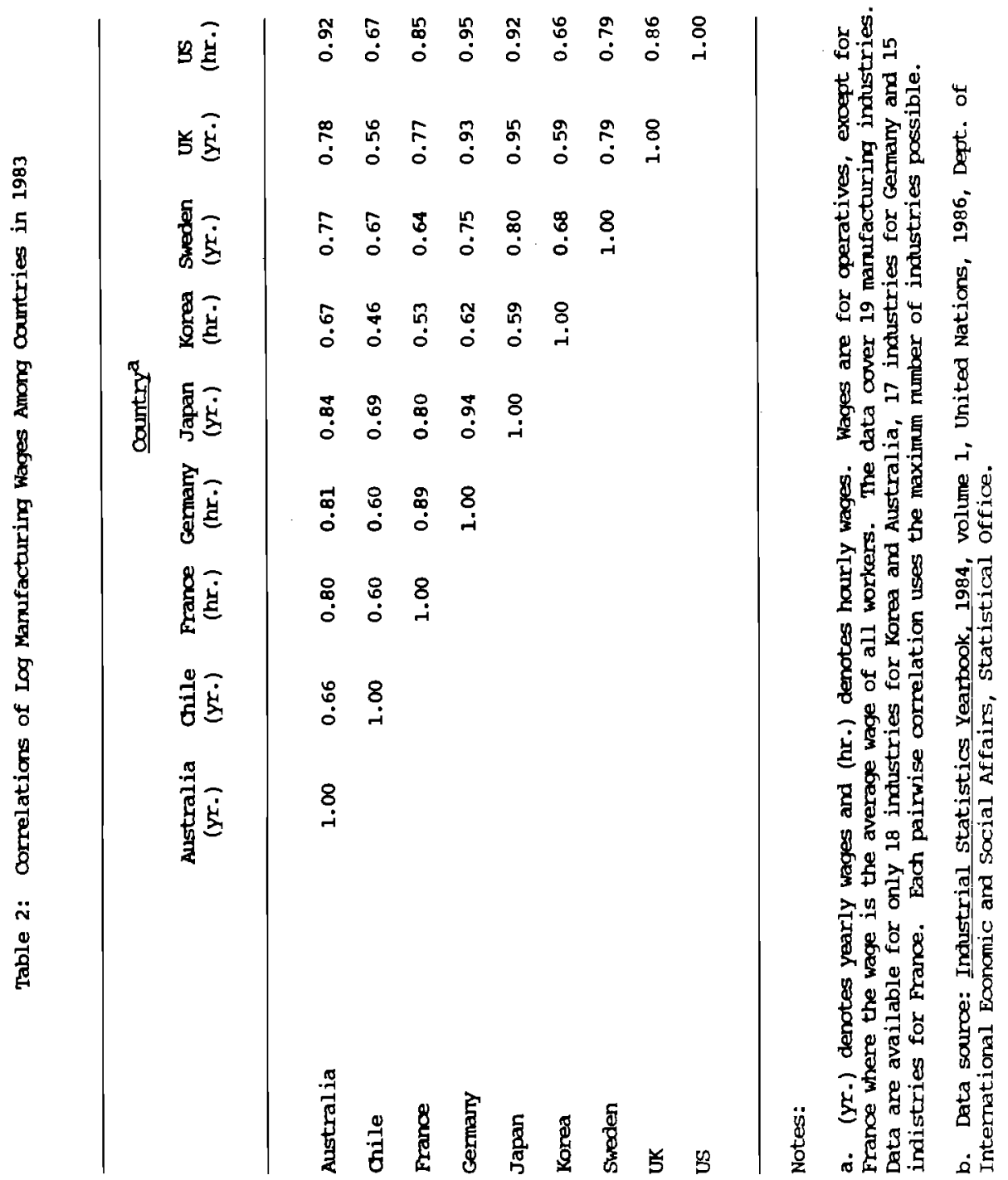




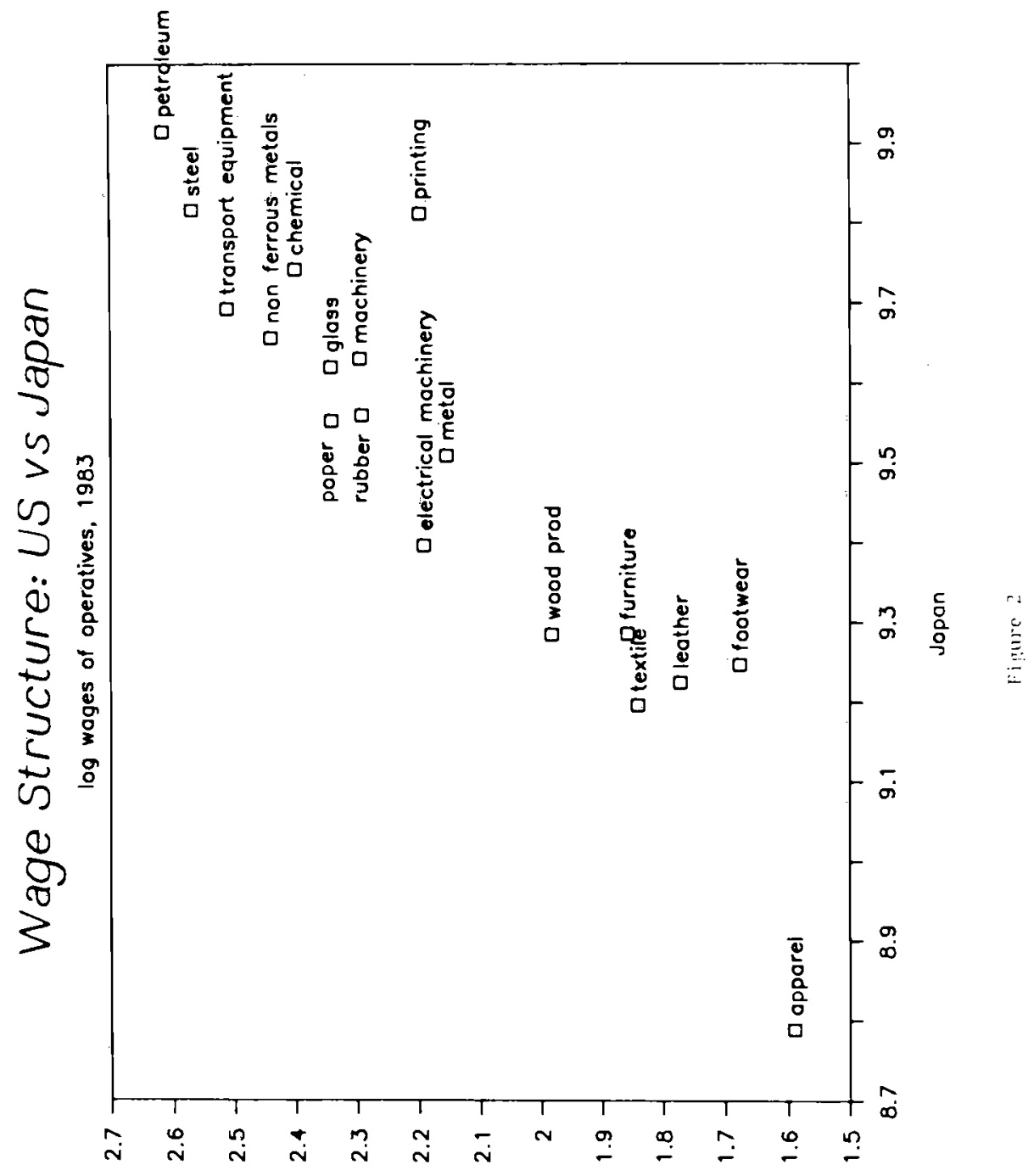


among a larger group of countries. The stability in differentials across time periods and countries strongly suggests that these wage differences result from factors fundamental to the operation of industrial economies and are not the artifact of particular collective bargaining systems or government interventions in the labor market.

The industry wage structure also appears to be very similar for different types of workers. Dickens and katz (1987b) find that inter-industry wage differentials are highly correlated across occupations: in industries where one occupation is highly paid, all occupations tend to be highly paid. For example, they find that the correlation in industry average wages for managers and laborers in 0.83 , even after controlling for worker characteristics. Furthermore, Krueger and summers (1988) show that the pattern of differentials is quite similar for young and old workers and for workers with short and long job tenure.

\section{The Characteristics of High-and Low-Wage Industries}

The evidence summarized above indicates that there exists a pattern of wage differentials in which all workers in some industries are paid more than similar workers in other industries. This raises the question of what are the attributes of high- and low-wage industries. Dickens and Katz (1987a) review the literature on the relations among industry characteristics and industry wages. They find that even after controlling for observed human capital, geographic, and demographic variables, both union and nonunion wages 
are positively correlated with capital-intensity, measures of product market power and ability-to-pay, union density, average education level, and firm and establishment size. High-wage industries also have much lower quit rates than low-wage industries.

The characteristics of high-wage and low-wage industries in U.S. manufacturing are illustrated in Figures 3a-3d. The tendency of capital intensive industries (and those with a low labor share) to pay high wages is apparent. The relation between R\&D spending and wages is less clear cut. Unfortunately, as Dickens and Katz note, it is not possible to reliably disentangle the independent effects of these factors on wages.

\section{Do Industry Wage Differentials Reflect Labor Rents?}

The competitive labor market model offers two types of explanations for persistent inter-industry wage differentials. These differentials may compensate for nonpecuniary differences in job attributes, or they may reflect differences in unmeasured labor quality. If compensating differentials and unobserved ability adequately explain the bulk of measured industry wage differences, then the presence of large industry wage differentials should not be an important consideration in the evaluation of trade policies.

Inter-industry wage differences do not appear to be easily explained by compensating differentials, for several reasons. First, Krueger and summers (1988) find that the inclusion of controls for observable differences in working conditions tends to increase rather than decrease estimates of the extent of inter- 
Figure 5

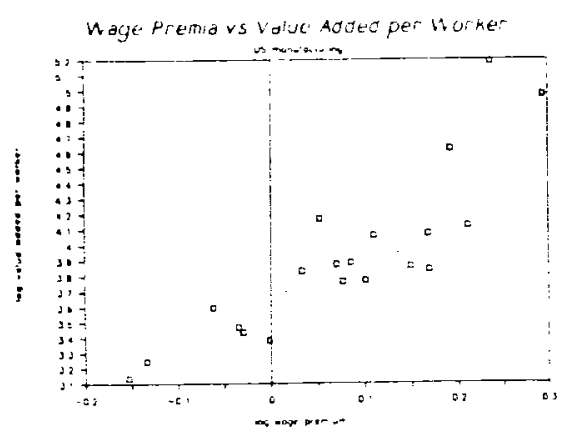

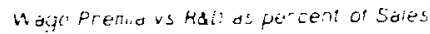

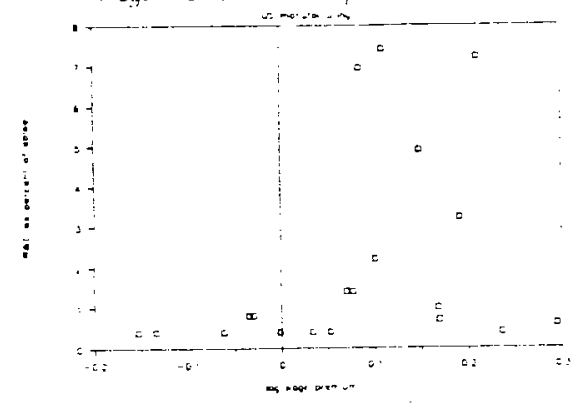

Maje Premia va Capilatilabar Hatio
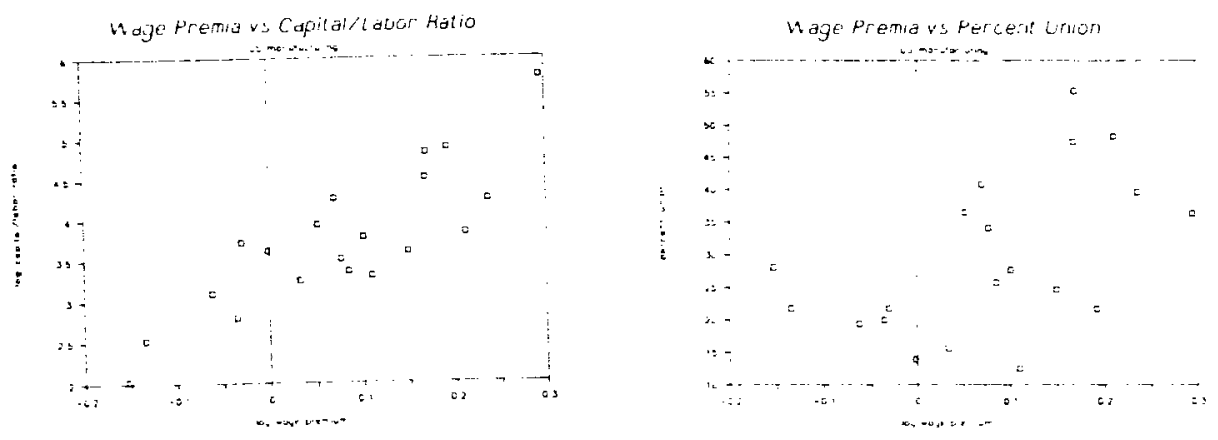
industry wage variation. Furthermore, the estimates in Table 1 indicate that the consideration of fringe benefits leads to substantially larger estimates of industry compensation differences. Thus, the consideration of observed nonwage compensation exacerbates the industry differentials.

Second, the strong correlation in inter-industry wage differences across occupations is also difficult to explain through equalizing differences, since it is unlikely that whenever working conditions are poor for production workers they are also poor for managers, secretaries, and salesmen. Third, Pencavel (1970) and many others have shown that there is a strong negative correlation between industry wage differentials and quit rates. Furthermore, Holzer, Katz and Krueger (1988) find that high-wage industries attract a greater number of job applicants per opening than do lowwage industries. These findings strongly suggest that workers in high-wage industries earn rents.

An alternative competitive explanation of these wage differences is that they largely reflect differences in workers' productive abilities that are not captured by the variables available in individual-level data sets. While it is almost certain that unobserved quality differences account for much of the variation in the wages that workers with similar observed characteristics receive, this does not necessarily imply that differences in the average wage paid in different industries are the result of differences in the average level of unobserved ability. Four types of evidence suggest that it is unlikely that a large part 
of measured inter-industry wage differences can be accounted for by unmeasured ability.

First, Krueger and summers (1988) find that after controlling for sex and occupation, controlling for other skill variables like education and experience has only a very small impact on the dispersion of industry wages. This is because there are only minor differences in educational attainment and in experience across industries after controlling for differences in occupational composition. Given the absence of a high degree of industrial sorting on the basis of observed labor quality proxies, a high degree of sorting on unobserved characteristics would be surprising. Second, Krueger and Summers (1988) present longitudinal evidence that when individual workers move between industries, either because of displacement or because of normal labor market processes, their wages change by amounts similar to the industry differentials estimated in cross-sectional regressions. 11 This finding casts some doubt on the hypothesis that measured interindustry wage differences are largely attributable to unobserved productive ability.

Third, much evidence indicates that more profitable industries, those with more monopoly power, and those where labor's share is smaller, pay higher wages. These regularities hold in different times and places and explain a sizable fraction of inter-industry

${ }^{11}$ See Murphy and Topel (1987) for contrasting findings using matched March CPS data. Gibbons and Katz (1987) discuss in detail potential reasons for differences in findings in alternative longitudinal data sets. 
wage variation. There is no obvious reason why these product market factors should be strongly correlated with unmeasured ability.

Fourth, the strong similarity in wage differences for different types of workers is also problematic for the unmeasured ability view. Why should industry technologies almost always have such strong skill complementarities that those requiring unusually good operatives require unusually good managers and clerical workers? Furthermore, industry differences in observed quality measures for different occupational groups do not appear to be nearly as strongly correlated as do their industry wage differentials. Dickens and Katz (1988) find that industry average education levels are only weakly positively correlated for many occupations and are negatively correlated for some groups.

our reading of the evidence is that it is difficult to account convincingly for the industry wage structure on the basis of unobserved ability differences or equalizing differences. Instead, it appears that workers in high wage industries earn rents.

\section{Alternative Explanations for Labor Market Rents}

The natural economic approach to explaining why firms in high wage industries fail to cut wages in the absence of any legal compulsion, is to isolate reasons why reducing wages would be unprofitable for a firm. This is the approach taken in the large and growing efficiency wage literature. The efficiency wage literature, surveyed in stiglitz (1987) from a theoretical perspective and Katz (1986) from an empirical perspective, has put 
forth a number of possible explanations for firms' failure to cut wages in the face of an excess supply of labor and their willingness to confer rents on incumbent workers.

A first explanation, emphasized by Shapiro and stiglitz (1984) in the context of unemployment and Bulow and summers (1986) in the context of wage differentials emphasizes the firms' need to deter their workers from shirking. Conferring rents on them, which will be forfeited if they are caught shirking, may be an efficient alternative to more extensive monitoring costs. This theory may rationalize the observation that capital intensive firms and those offering more job autonomy pay higher wages because the cost of shirking is higher in these firms. Krueger (1987) provides some supporting evidence by documenting that fast food firms appear to trade-off wages and monitoring effort.

A second explanation revolves around firms' desire to avoid turnover because of fixed hiring and training costs. This explanation elegantly modelled by stiglitz (1985) is consistent with the observation that wage premia appear to be somewhat larger for experienced than for inexperienced workers. It is also supported by frequent references to the need to monitor turnover in personnel books. A third related explanation for firms' willingness to confer rents involves adverse selection considerations (Weiss, 1980). If more able workers have higher reservation wages than their less able counterparts, firms that reduce wages may find that the average ability of their work force declines so rapidly that unit labor costs increase. This explanation is consistent with the complaints 
of some managers that the "wrong" workers quit in good times.

While each of these explanations can be formalized, they appear insufficient to fully account for the observed pattern of wage differentials. A striking feature of this pattern is the similarity in industry wage patterns for different occupational groups. It is difficult to see why workers in industries with an especially great need to motivate and retain operatives should also have an especially great need to motivate and retain clerical workers. The similarity of wage patterns in different occupations along with the observation that monopoly power appears to influence wages, suggest that firms for which production interferences are especially costly may pay abnormally high wages even in non-union settings.

This type of behavior can be justified on the grounds of "gift exchange" theories of the type advanced by Akerlof (1984). In these models, a worker's effort depends on his perception of how fairly he is being treated. Perceived fairness in turn depends on how profitable the firm is. A related argument might hold that firms pay high wages to "buy the peace", avoiding unions or collective visible shirking of the kind that Mathewson (1969) and Mars (1982) find in many industrial settings. The "peace" may be worth more to some firms than others. A final explanation invokes expense preference behavior on the part of managers, who may particularly at low levels feel more loyalty to employees than shareholders. If the efficiency effects of wage increases described in previous paragraphs are important, it may not be very costly for firms to raise wages. 


\section{Conclusion}

The evidence in this section suggests that industry wage differentials for similar workers are substantial. It appears that these wage differentials largely reflect rents earned by workers in high wage industries. No doubt, industry wage differences result from a number of sources. Fortunately, as we argue in the next section, the implications of non-competitive wage differentials for trade policies are similar for a variety of underlying causes of the differentials as long as firms choose employment levels on their labor demand curves.

\section{Wage Differentials and Trade Policies}

The basic argument linking labor market imperfections and trade policies has long been recognized by trade theorists (see for example Bhagwati and Srinivasan (1983) and Magee (1976)). It has been echoed, though in a less clear fashion, in the American debate over industrial policies. If competitive forces do not equalize wages in different sectors and if firms operate on their labor demand curves, then the marginal product of labor in different sectors will not be equated, resulting in allocative inefficiencies. Policies which raise employment in high wage sectors at the expense of employment in low wage sectors will therefore increase allocative efficiency. This line of argument captures the thrust of industrial policy arguments suggesting that countries can raise their workers' 
standards of living by encouraging the growth of "high value added industries".

We begin by demonstrating that the interaction of trade policies with wage differentials has welfare consequences that are likely to be more important to the profit shifting effects that have been the focus of recent discussions of strategic trade policy. Then we examine arguments against subsidies to employment in high wage sectors based on rent seeking and equity considerations. We conclude that on economic grounds there is a reasonably strong welfare argument for measures that promote production in high wage industries, though any policy judgment must depend on an assessment of how skillfully the government would manage its interventions.

\section{Wage Differentials In A Closed Economy}

For simplicity, consider a stylized economy with two sectors. 12 Following the terminology of Doeringer and piore (1971), we label these sectors secondary and primary. As we discuss below, the primary sector pays higher wages and offers workers more responsible jobs than the secondary sector. Secondary sector output, taken as the numeraire, is given by $\mathrm{Y}^{\mathrm{n}}=\mathrm{w}_{0} \mathrm{~L}^{\mathrm{n}}$. The secondary sector labor market is competitive so that workers employed in the secondary sector receive a wage equal to their marginal product, $w_{0}$. Primary sector output is given by the constant returns to scale production

12 At the cost of some complexity, the special assumption that capital is not used in producing secondary sector output could be relaxed. It does capture the stylized fact noted in the previous section that high wage sectors tend to be capital intensive. 
function $\mathrm{Y}^{\mathrm{P}}=\mathrm{F}\left(\mathrm{K}^{\mathrm{P}}, \mathrm{L}^{\mathrm{p}}\right)$. The demand for primary sector output is a decreasing function of its price, $\mathrm{p}=\mathrm{p}\left(\mathrm{Y}^{\mathrm{p}}\right), \mathrm{p}^{\prime}<0$. We assume that the wage differential, $d$ in the primary sector is a nondecreasing function of employment, $d=d\left(L^{p}\right), d^{\prime} \geq 0.13$ It may depend positively on the level of employment because workers' ability to extract rents is increased when the demand for labor increases, or because the costs of leaving a high-wage job is reduced when there are more high-wage jobs in the economy.

Assume initially that the economy is closed and that the capital stock is fixed. Firms in the primary and secondary sector product markets are assumed to act competitively. Then the first order condition:

$$
p\left(Y^{p}\right) F_{L}\left(K^{p}, L^{p}\right)=w_{0}(1+d)
$$

determines the level of primary sector employment. This level of primary sector employment is inefficiently low. As Figure 4 illustrates, a subsidy to employment in the primary sector at a rate just sufficient to offset the wage differential $(1 /(1+d))$ would permit the economy to attain the first best allocation of labor. 14 Note that such a subsidy increases efficiency, even though it may lead to a widening of inter-industry wage differentials. We return below to the question of whether or not it represents a Pareto

\footnotetext{
${ }^{13}$ See Bulow and summers (1986) for an explicit derivation of a $d\left(L^{P}\right)$ schedule from an efficiency wage model.

${ }^{14}$ The optimal subsidy will be set at $d\left({ }^{p}{ }^{\prime}\right)$ where ${ }^{p}$, is the level of primary sector employment where $\mathrm{p}\left(\mathrm{Y}^{\mathrm{p}}\right) \mathrm{F}\left(\mathrm{K} \mathrm{p}^{\mathrm{L}}, \mathrm{L}^{\mathrm{p}}\right)=\mathrm{w}_{0}$.
} 
Figure 4

Subsidies and Economic Efficiency

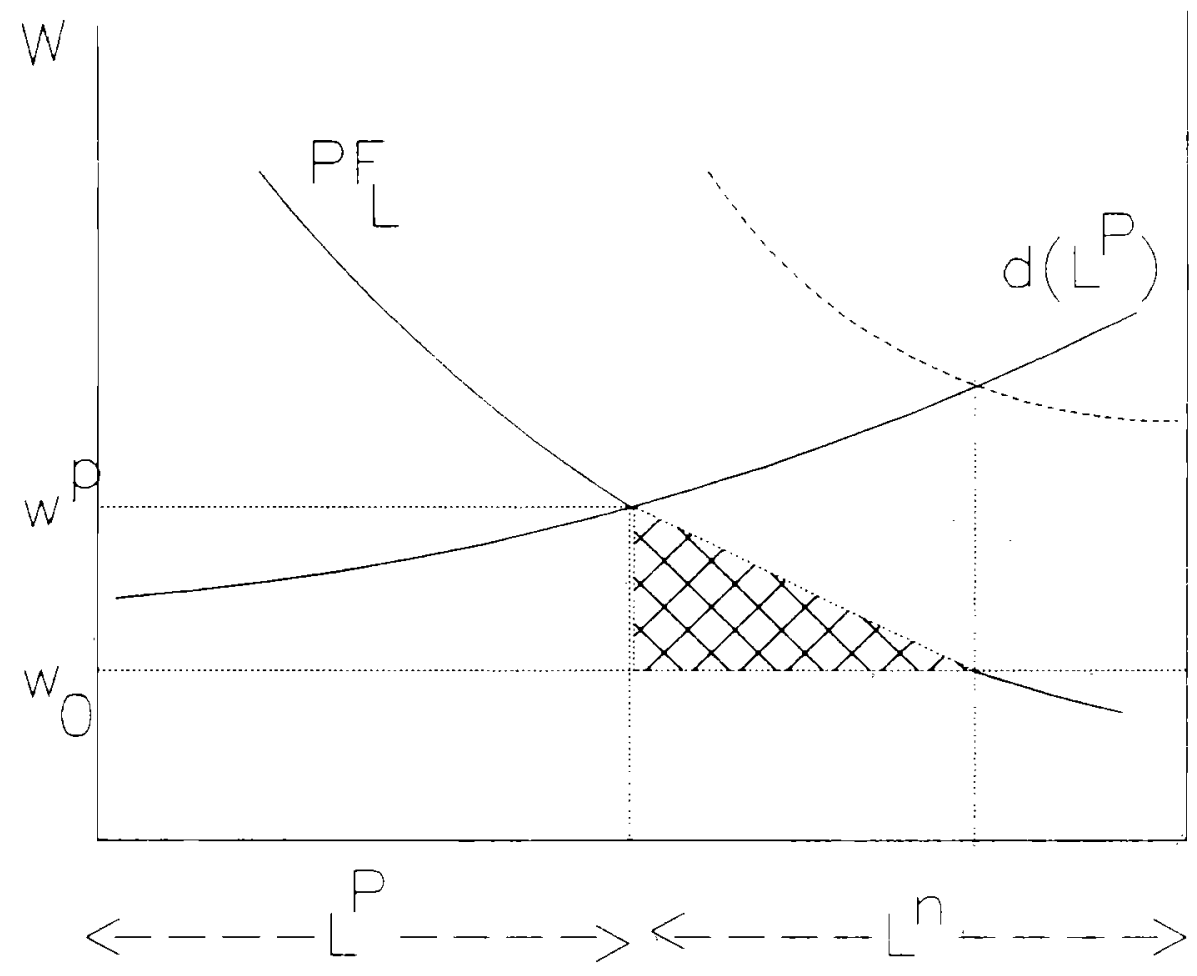


improvement.

So far we have maintained the assumption of perfect competition in product markets and the assumption that the capital stock in each industry is fixed. Relaxing these assumptions tends to strengthen the case for policies directed at expanding the primary sector. If firms in the primary sector have market power, this is another reason apart from wage premia why the social marginal product of labor in the primary sector exceeds the social marginal product of labor in the secondary sector. Put more directly: there is an efficiency case for subsidizing the variable inputs of a monopolist.

Allowing for variable capital input strengthens the case for subsidies to high-wage industries. If wage differentials do not depend on the capital intensity of the primary sector, then the appropriate policy instrument in the presence of noncompetitive wage differentials is a wage subsidy. If wage differentials are an increasing function of capital intensity as some rent-sharing theories would suggest, then there is a case for capital investment subsidies to offset the "tax" levied by labor on capital investments.

How substantial are the potential gains from public policies directed at offsetting the effects of inter-industry wage differentials? One way of answering this question is by comparing the efficiency costs of inter-industry wage differentials with other distortions that have received more attention from economists. Section II showed that the standard deviation of nonunion industry compensation differences after correcting for measured ability 
differences was about $18 \%$. About $15 \%$ of private sector American workers are covered by trade union agreements, and it is generally estimated that their compensation is about $20 \%$ above those of other workers. If this were the only source of wage inequality, the standard deviation of wages would be approximately $7 \%$. This suggests that the allocative inefficiency attributable to industry wage effects is at least comparable to the efficiency costs arising from union wage differentials.

A different standard of comparison is the distortionary consequence of taxation. Assuming that labor's share in output is about three-quarters, a $20 \%$ differential in labor costs between two sectors, will affect the product $\mathrm{mix}$ in the same way as a $60 \%$ capital income tax, or a $15 \%$ sales tax. The former figure is more than what is at stake in the much discussed distortion between corporate capital and owner occupied housing. Much smaller differentials in effective tax rates played a prominent role in the recent us tax reform debate. Discussions of sales taxes invariably treat differences of only a few percentage points in the rates on included and excluded items as a serious problem.

Inter-industry wage differences appear to cause allocative distortions greater than those resulting from trade unions or the corporate income tax. A different way of demonstrating their importance is by evaluating the marginal social product of capital in the primary sector in their presence. The value of output measured at pre-intervention prices in our stylized economy is given by 
(2) $Y=p F\left(K^{p}, L^{p}\right)+w_{0} L^{n}$,

where $L^{n}+L^{p}=L$ and $L$ is the fixed stock of labor in the economy. Differentiating (2) with respect to $\mathrm{K}^{\mathrm{P}}$, the primary sector capital stock, and then using both the first order condition (1) and the assumption that the primary sector production function displays constant returns to scale, we obtain the result:

(3) $d Y / d K^{P}=r(1+[\alpha d /(1-\alpha)(1+d)])$,

where $Y$ represents the total value of national income, $r$ is the return received by the suppliers of capital, and $\alpha$ represents labor's share in the primary sector. Taking labor's share to be $3 / 4$, and the wage differential to be $20 \%$, this implies that the marginal product of additional capital in the primary sector is inflated by $1 / 2$ because of the preexisting wage differential. This suggests that substantial gains may be achievable by targeting investment incentives towards high wage sectors.

\section{Wage Differentials in a Small open Economy}

In the case of a small open economy, illustrated in Figure 5 , the relative price of primary sector output is determined on international markets and is assumed to be unaffected by the domestic production mix. The demand function $\mathrm{p}\left(\mathrm{Y}^{\mathrm{p}}\right)$ becomes perfectly elastic. This does not change the condition (1) or the 
desirability of employment subsidies for the primary sector. opening up the economy does however strengthen the case for large subsidies. In a closed economy, subsidies to the primary sector encounter diminishing returns as its output declines in value with increased production. This does not happen when the price of output is set on world markets and is insensitive to the level of domestic production. 15

There is a further point to be made. As Figure 5 illustrates, the marginal welfare gained per dollar of subsidy will be greater the greater is the world price of primary sector output. As the world price of primary sector output expands, and so domestic production expands, the wage differential increases, raising the social gain to inducing further expansion of the primary sector. This observation resonates somewhat with discussions of industrial policy that claim that governments should support "sunrise" export industries rather than "sunset" import competing industries.

We have focused on the desirability of employment or production subsidies for the high wage sector. An obvious alternative is protection, through the exclusion of foreign competition. As illustrated in Figure 6, protection has the virtue of expanding the

15 We focus on the "small open economy case" to highlight the implications of wage differentials for trade policy. In the case of open economies large enough to affect the prices at which they buy and sell, there are traditional optimal tariff considerations as well. These suggest the desirability of taxing rather than subsidizing exports when expanding exports can lead to at least a moderate terms-of-trade deterioration. In this case, our analysis of employment subsidies is correct if it is assumed that optimal tariffs (taxes) based on these traditional considerations are already in place. 
Figure 5

Subsidies in Closed and Open Economies Wages

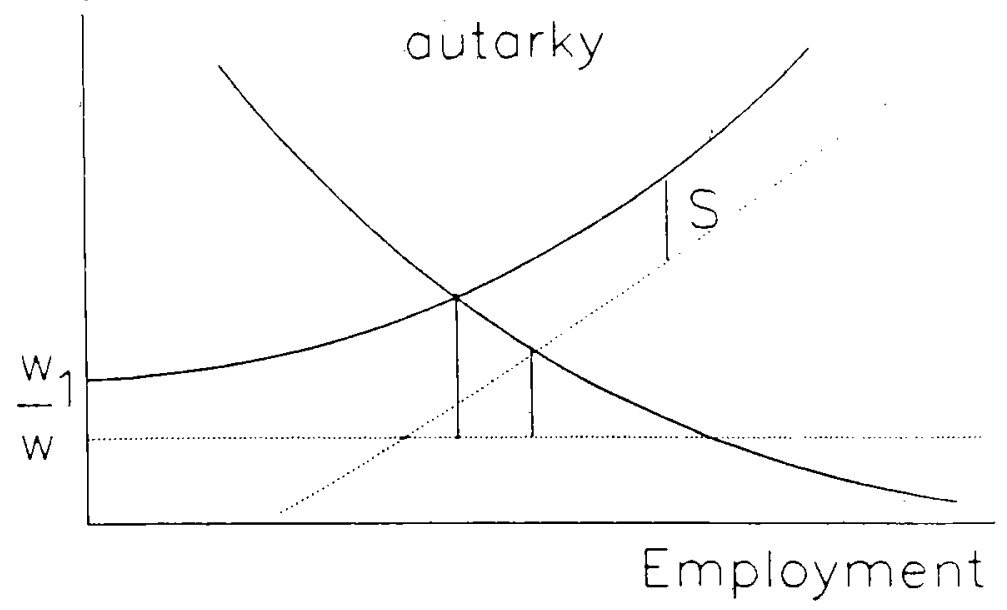

Wages

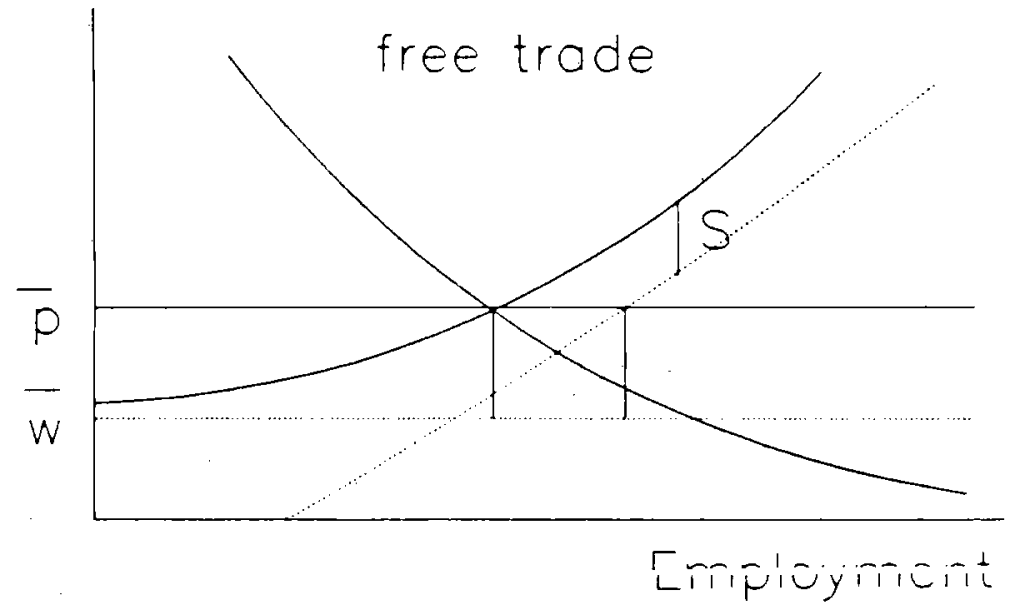


Figure 6

The Gains and Losses from Protection

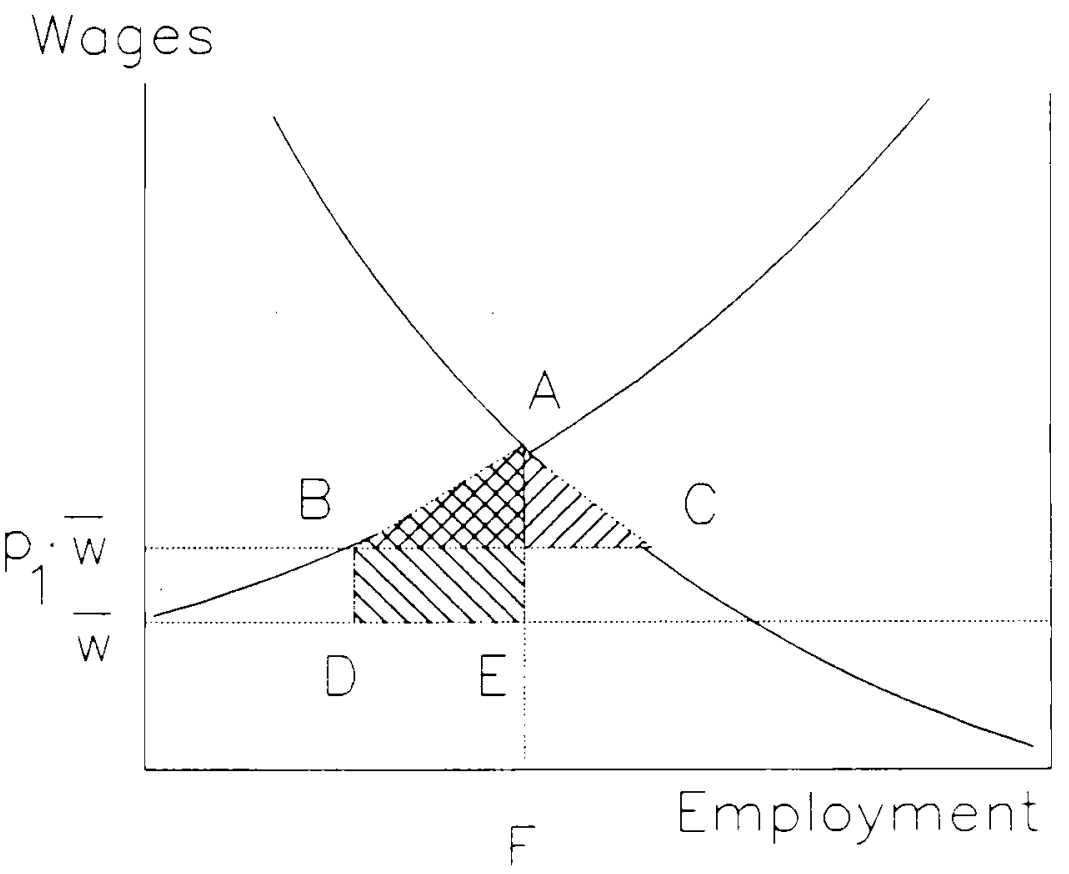
Alily
DIIIIA
Loss from
Gain from
Trade
Trade 
primary sector but the disadvantage of raising the sonsumer price of the primary sector good. It is clear from the figure that the former effect is first order while the latter effect is second order. It follows that at least small movements towards protection will be welfare enhancing, though they will be less desirable than primary sector employment subsidies. This is an illustration of the general principle discussed by Bhagwati and srinivasan (1983), that in the presence of distortions, policies can be ranked, with instruments that most directly address distortions being preferred. Discussions of activist trade policies typically stress the potential defect that they invite retaliation, which offsets any initial benefits. This argument does not apply when policy options are limited to subsidies directed at capturing labur market rents. In the model considered here, it is true that countries would prefer that their subsidies to primary sector output not meet retaliation. In our model, however, subsidies that are retaliated against by similar subsidies are nonetheless likely to raise the welfare of both countries. ${ }^{16}$ This is because they will drive the world economy to a situation like subsidized first best optimum depicted in Figure 4. Note further that subsidies beyond the point where the marginal product of labor in the primary and secondary sectors are equated are inefficient in both open and closed economies.

\section{Gauging the Importance of Labor Rents}

Under most plausible estimates, the wage differential effects

$$
{ }^{16} \text { This point has also been made by Dickens and Lang (1988). }
$$


stressed here are of greater importance for trade policy than the product market monopoly rent shifting effects discussed in recent work on strategic trade policy. The social return to increased investment in the presence of wage differentials can easily be as much as 50 percent greater than the private gain. The point may be illustrated more strongly by considering two recent studies of strategic trade policies--Baldwin and Krugman's (1987a,b) study of European subsides to Airbus Industrie for the development of the A300 jet; and Dixit's (1988) study of trade in automobiles.

Baldwin and Krugman construct a simple simulation model incorporating both learning curve effects and strategic interactions in aircraft industry. Their data indicate that the subsidy had very substantial effects on the allocation of airplane production between the United States and Europe. It also reduced prices in the industry considerably. The Baldwin-Krugman analysis suggests that the subsidy program cost $\$ 1.47$ billion in profits for the European airline industry, and increased the consumer surplus of European customers by $\$ 1.43$ billion, leading to only a negligible change in economic welfare. Their analysis takes no account of the rents gained by labor as it moved from lower-wage industries into the high-wage airplane industry, however. A policy analysis should not treat the rent component of the wage bill as a social cost of production but as a component of the social surplus generated by the industry. 17

${ }^{17}$ This point is well known from the development literature on project evaluation (e.g. Sah and stiglitz, 1985). 
To estimate the "labor rent" effects of the Airbus program, we assumed alternatively that compensation in the entire product chain of airplanes was 25 percent higher than the economy average and that it was 25 percent higher in only the final stage of production -airline assembly. Combining these figures with Baldwin and Krugman's estimates of the diversion of sales towards the Airbus consortium and information on the labor's share in airplane production permits a rough estimate of the labor rent shifting effect of the Airbus subsidy of the A300.

The results in Table 3 indicate that once labor rent considerations are recognized, the overall assessment of the Airbus program for European-welfare turns from marginally negative to strongly positive. Even in the less favorable case, the subsidy generates a welfare gain representing about half its cost. The estimated gain would be far greater, recognizing the high level of unemployment in Europe, if we assumed that some of those hired by Airbus would otherwise have been unemployed.

A similar conclusion is suggested by Dixit's recent study of the automobile industry. He finds that allowing for labor rents in the American automobile industry dramatically alters the results of his analysis based on imperfect competition in the product market. Policies promoting domestic production that appear undesirable without taking account of labor market imperfections yield large gains once the existence of these imperfections is acknowledged.

More careful empirical analysis of more specific incidents is needed before firm judgments about the potential importance of labor 
Table 3: Labor Market Rents and the Effects of the Airbus A300 Program on European Welfare ${ }^{a}$

\section{Scenario}

(1)

$\begin{array}{ll}\text { No labor } & 208 \text { Labor rents } \\ \text { rents } & \text { at final stage } \\ \text { of production }\end{array}$

(3)

208 Labor rents at all stages of production

\begin{abstract}
Change in present discounted value of consumer surplus
\end{abstract}

Change in present discounted value of profits

Change in present discounted value of labor rents of

(n)

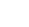

$$
+1.43
$$

$+1.43$

$+1.43$

(n)

$+1.43+1.43+1.43$


rent shifting can be made. The examples here were selected by other authors because of potentially important product market imperfections. It would be valuable to examine industries, such as steel, that are noted for large labor market imperfections.

\section{Some Possible objections}

our analysis so far has assumed away rent seeking behavior. At least two types of rent seeking need to be considered. First, it is possible that wage differentials generate wait unemployment of the sort envisioned by Harris and Todaro (1970). In the extreme case where the primary sector hires randomly each period from a pool of waiting applicants, ${ }_{\mathrm{w}^{\mathrm{p}}}^{\mathrm{p}}(1-\mathrm{u})=\mathrm{w}^{0}$ where $\mathrm{u}$ is the unemployment rate in the primary sector. In this case, there is no gain to increasing primary sector employment, since for each job created in the primary sector, $u /(1-u)$ workers move from the low wage sector into unemployment (Harberger, 1971). ${ }^{18}$ A more plausible formulation of wait unemployment would recognize that incumbent emoloyees typically retain the rights to their jobs each period so that only new openings and those jobs where the incumbent worker has quit or been terminated are available to be allocated to the unemployed. Under this scenario, if workers have positive discount rates and enter the primary sector queue to the point where the utility of being in the queue equals the utility of being employed in the low wage sector,

${ }^{18}$ since each new job created in the primary sector removes $1 /(1-u)$ workers from secondary employment and since $w_{0} /(1-u)=w^{p}$, the social opportunity cost of labor for an additional job in the primary sector equals the marginal product of labor in the primary secto 
extra employment in the primary sector will generate less induced unemployment than in the initial case considered. Thus, a small subsidy to the primary sector will still be desirable. ${ }^{19}$ Furthermore, if workers are able to queue for high wage jobs from low wage jobs, rent seeking through wait unemployment may not be an important problem.

The second type of rent seeking behavior involves efforts to create wage differentials. Union organizing drives are an obvious example. If larger wage differentials lead to larger employment subsidies, such rent seeking activity will be encouraged. In this case, subsidies to high wage industries, while increasing efficiency ex-post may create large ex-ante inefficiencies if they lead to more resources being devoted to trying to push up wages. We doubt that this point is of vast practical importance. Union organizing budgets and employer resistance expenditures are trivial compared to the rents earned by union workers. Taking $20 \%$ of the workforce to be unionized and a $20 \%$ union compensation effect implies that $4 \%$ of wages, or about $\$ 75$ billion a year represents rents. Union organizing budgets in the U.S. certainly total far less than $\$ 1$ billion. Furthermore, the evidence surveyed in the previous section suggests that most wage differentials do not arise from organizing activity.

A different line of argument against policies directed at subsidizing the primary sector stresses their anti-egalitarian

${ }^{19}$ See Sah and stiglitz (1985) and the references therein for a more detailed discussion of wait unemployment and the measurement of the social opportunity cost of labor. 
consequences. The essence of such policies is, after all, subsidizing workers who are receiving relatively high wages. The argument is more subtle, however, than it at first appears. Subsidies to the primary sector enlarge it, thereby raising the probability of secondary sector workers being able to move into the primary sector. Bulow and summers (1986) demonstrate that small subsidies to the primary sector are Pareto improvements relative to laissez faire, in the special case where all workers are homogeneous, movements between sectors can be characterized by a Markov process, and efficiency wage considerations lead to constant lifetime utility differences between workers in the two sectors. More generally, efficiency enhancing subsidies will not produce Pareto improvements, particularly if there are some secondary sector workers who have no chance of getting primary sector jobs because of their lack of skill. It is of course possible to argue that optimal subsidies should be given to improve the allocation of output, and then income redistribution measures should be used to offset any perverse distributional consequences. 20

On balance, the arguments in this section suggest that there is a legitimate economic argument in support of policies directed at encouraging production in high-wage sectors of the economy. Even though such measures are likely to increase wage differentials, they

20 The issue is a complex because policies that tax high wage workers for the benefit of low wage workers will, at least in some efficiency wage models, have perverse effects on the composition of output by reducing the relative utility of primary sector workers. Thus, income redistribution policies may undo the allocative effects of subsidies to sectors with that pay wage premia. 
nevertheless may increase economic welfare. Especially in nonunion contexts, it appears unlikely that rent seeking losses will outweigh the gains achievable through increasing high wage employment.

IV. Wage Differentials and American Trade Policies

The belief that international competition is profoundly changing the economic landscape and leading to the deindustrialization of America is often expressed in debates over American industrial policy. The crude argument that the united states is losing its manufacturing base to international competitors is often put forward as a justification for policies directed at limiting imports or spurring exports. In George Meany's picturesque phrase, "you cannot have a healthy economy based on everyone doing everyone else's laundry".

The claim that the United States might lose its ability to compete in all industries rests on confusion. As long as foreigners are unwiling to indefinitely accumulate claims on American assets, the United States must ultimately run a surplus. The interesting question for structural trade policy is therefore whether trade balance with a high level of both exports and imports or with a low level of both exports and imports is preferable.

To shed light on this issue, Tables 4 and 5 presents information on the characteristics of American manufacturing industries, distinguishing between "import" and "export" industries. We focus only on manufacturing because of data limitations regarding other sectors, and because manufacturing accounts for the lion's 
share (about 2/3) of American trade. 21 The data refer to threedigit. census industries. The number of import or export workers in each industry is estimated as the product of the industry's total number of employees and the fraction of total industry shipments represented by imports or exports.

Table 4 lists the manufacturing industries with the highest import and export shares. Most of the export industries rely heavily on high technology, aircraft being a prominent example. The import industries are more mixed, ranging from footwear to office machines to motor vehicles. Particularly in the case of export industries, it is striking that durable and capital goods play an important role in merchandise trade.

Intraindustry trade is very important even at the three digit level; the correlation between import and export shares was 0.06 in 1983. To highlight the differences between import and export workers, the first three columns of Table 5 compare the average characteristics of the most import and the most export intensive industries with those of the entire manufacturing sector.

A clear pattern emerges from the Table. Relative to the entire manufacturing sector, export industries look much more like the primary sector firms described by Doeringer and Piore (1971), while import industries look much more like secondary sector firms. Wages in export intensive industries are 12 percent above average after adjusting for skill differences, while wages in import intensive

${ }^{21}$ see Dickens and Lang (1988) for consideration of the relation between U.S. trade and wages outside of the manufacturing sector. 
Table 4: High Import Penetration and Export Supply Ratio Three-Digit Census Industries in U.S. Manufacturing - 1983

Industries Employing Top 10 of Workers by Import Penetration Ratio ${ }^{a}$

\begin{tabular}{llllr} 
CIC Industry & $\mathrm{M} /(\mathrm{M}+\mathrm{S})$ & $\mathrm{X} / \mathrm{S}$ & $\begin{array}{c}\text { Log Wage } \\
\text { Premium }\end{array}$ & $\begin{array}{c}\text { Enployment } \\
\text { (1000s) }\end{array}$ \\
\hline 381 Watches, Clocks, and & .511 & .085 & -.242 & 14.6 \\
$\begin{array}{l}\text { Watchcases } \\
221 \text { Footwear, Except Rubber }\end{array}$ & .511 & .024 & -.174 & 119.6 \\
222 Leather Products & .371 & .041 & -.166 & 49.7 \\
391 Jewelry and Misc. & .335 & .084 & -.120 & 278.6 \\
$\begin{array}{l}\text { Manufacturing } \\
261 \text { Pottery }\end{array}$ & .332 & .108 & -.142 & 37.5 \\
321 Office and Accounting & .283 & .148 & .069 & 66.3 \\
$\begin{array}{l}\text { Machines } \\
\text { Toys, Amusenents, and }\end{array}$ & .260 & .113 & -.095 & 96.4 \\
$\begin{array}{l}\text { Sporting Goods } \\
\text { Apparel and Accessories }\end{array}$ & .214 & .016 & -.216 & 1014.9 \\
351 Motor Vehicles & .204 & .087 & .174 & 658.6 \\
\hline
\end{tabular}

Industries Employing Top 108 of Workers by Export Supply Ratioc

\begin{tabular}{llccc} 
CIC Industry & $\mathrm{X} / \mathrm{S}$ & $\mathrm{M} /(\mathrm{M}+\mathrm{S})$ & $\begin{array}{c}\text { Log Wage } \\
\text { Premium }\end{array}$ & $\begin{array}{c}\text { Employment } \\
\text { (1000s) }\end{array}$ \\
\hline 352 Aircraft and Aircraft & .438 & .051 & .153 & 527.0 \\
$\quad \begin{array}{l}\text { Parts } \\
312 \text { Construction Machinery }\end{array}$ & .318 & .059 & .110 & 346.7 \\
322 Electronic Computing & .263 & .115 & .083 & 354.4 \\
$\quad \begin{array}{l}\text { Equipment } \\
310 \text { Engines and Turbines }\end{array}$ & .252 & .053 & .227 & 95.6 \\
371 Scientific Instruments & .235 & .111 & .020 & 264.4 \\
361 Railroad Equipment & .208 & .070 & .194 & 25.0 \\
191 Agricultural Chemicals & .183 & .055 & .035 & 45.9 \\
192 Industrial Chemicals & .173 & .081 & .169 & 322.6
\end{tabular}

\footnotetext{
Notes:
The employment weights used in calculations for the Top 10 s import workers are actual employment for the top 8 industries and 67,200 for motor vehicles.

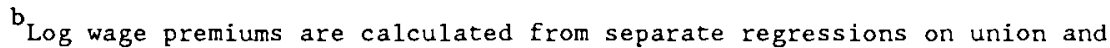
nonunion samples from the Full Year 1983 CPS. The log wage premium for an industry equals ([(UD + 0.192)*UCOV\} + NUD*(1-UCOV)) where UD is the estimated industry wage premium for union workers, NUD is the premium for nonunion workers, UCOV is the fraction of workers in the industry covered by union agreements, and 0.192 is the estimated union-nonunion wage differential for the Full Year 1983 CPS from Katz (1986).

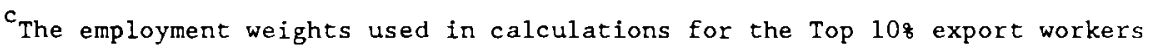
are actual employment for the top 7 industries and 185,800 for industrial chemicals.
}

Sources: NBER Trade-Immigration-Labor Market Data Set and Dickens-Katz (1987a) Industry Data Set. 
Table 5: Characteristics of Typical Import and Export Workers in U.S. Manufacturing Industries - 1983

\begin{tabular}{|c|c|c|c|c|c|}
\hline & $\begin{array}{l}\quad \text { (1) } \\
\text { Typical } \\
\text { Manuf. } \\
\text { Worker }\end{array}$ & $\begin{array}{l}\text { (2) } \\
\text { Top 108 } \\
\text { Imports }\end{array}$ & $\begin{array}{l}\text { (3) } \\
\text { Top 10\% } \\
\text { Exports }\end{array}$ & $\begin{array}{l}\quad(4) \\
\text { Typical } \\
\text { Import } \\
\text { Worker }\end{array}$ & $\begin{array}{l}\quad(5) \\
\text { Typical } \\
\text { Export } \\
\text { Worker }\end{array}$ \\
\hline $\begin{array}{l}\text { Average Hourly Wage } \\
\text { for Production Workers }\end{array}$ & $\begin{array}{l}8.88 \\
(1.93)\end{array}$ & 6.03 & 10.37 & 8.36 & 9.60 \\
\hline $\begin{array}{l}\text { Log Wage Premium } \\
\text { for All Workers }\end{array}$ & $\begin{array}{l}0.00 \\
(.115)\end{array}$ & -.163 & .116 & -.022 & .054 \\
\hline $\begin{array}{l}\text { Log Wage Premium } \\
\text { for Nonunion Workers }\end{array}$ & $\begin{array}{l}0.00 \\
(.10)\end{array}$ & $\cdot .135$ & .128 & -.015 & .059 \\
\hline $\begin{array}{l}\text { Pct. Wage Premium } \\
\text { for union Workers }\end{array}$ & $\begin{array}{l}0.00 \\
(.12)\end{array}$ & -.214 & .071 & -.051 & .035 \\
\hline Percent Female & $\begin{array}{l}33.7 \\
(18.5)\end{array}$ & 68.5 & 24.8 & 40.3 & 28.2 \\
\hline Percent Immigrants & $\begin{array}{l}8.1 \\
(4.3)\end{array}$ & 17.0 & $6.6^{\circ}$ & 10.0 & 7.3 \\
\hline Percent Black & $\begin{array}{l}10.3 \\
(3.6)\end{array}$ & 12.3 & 7.1. & 10.7 & 8.7 \\
\hline Percent Unionized & $\begin{array}{c}29.8 \\
(13.9)\end{array}$ & 27.4 & 28.0 & 30.1 & 29.7 \\
\hline $\begin{array}{l}R \& D \text { Expenditures as } \\
\text { a Percent of Sales }\end{array}$ & $\begin{array}{l}2.9 \\
(3.5)\end{array}$ & 1.1 & 8.7 & 3.1 & 5.5 \\
\hline $\begin{array}{l}\text { Percent Production } \\
\text { Workers }\end{array}$ & $\begin{array}{c}68.2 \\
(13.1)\end{array}$ & 79.8 & 52.1 & 70.9 & 62.4 \\
\hline $\begin{array}{l}\text { Average Years of } \\
\text { Schooling }\end{array}$ & $\begin{array}{l}13.1 \\
(0.8)\end{array}$ & 12.0 & 14.1 & 12.9 & 13.5 \\
\hline $\begin{array}{l}\text { Value Added Per Worker } \\
\text { (thousands of dollars) }\end{array}$ & $\begin{array}{c}50.5 \\
(22.6)\end{array}$ & 28.8 & 59.3 & 45.4 & 54.2 \\
\hline$M /(M+S)$ (in percent) & $\begin{array}{c}9.7 \\
(8.2)\end{array}$ & 27.0 & 7.8 & 18.5 & 10.0 \\
\hline $\mathrm{X} / \mathrm{S}$ (in percent) & $\begin{array}{c}9.0 \\
(9.2)\end{array}$ & 4.4 & 30.6 & 9.0 & 18.5 \\
\hline
\end{tabular}

Columns (1), (2), and (3) are three-digit Census industry averages weighted by industry employment. Import and Export rankings based on 1983 trade data. Columns (2) and (3) present average characteristics of the top $10 \%$ of workers by industry $M /(M+S)$ and $X / S$ respectively. Columm (4) presents three-digit Census industries weighted by industry employment times M/S. Column (5) presents three-digit Census industries weighted by industry employment times $X / S$. The numbers in parentheses are standard deviations.

$\mathrm{M}=$ imports, $\mathrm{X}=$ exports, $\mathrm{S}=$ shipments of domestic producers.

Sources: Dickens-Katz 1983 Industry Data Set described in Dickens and Katz (1987) and NBER Trade-Immigration-Labor Market Industry Data Set. 
industries are 16 percent below average. Roughly similar

differentials are observed for both union and non-union workers. The widely cited examples of automobiles and steel, where very high wage industries face substantial import penetration and are almost completely unable to export, appear to be atypical. The general pattern is that export intensive industries are the ones with substantial wage premia.

Reflecting patterns of American comparative advantage, export intensive industries in the United States also employ more skilled workers and do more research and development than import intensive industries. Export intensive industries devote 8.7 percent of sales to research and development, compared to 1.1 percent for import intensive industries. The average worker in export intensive industry has 14 years of schooling, compared with 12 years for the average worker in import intensive industry. Import intensive industries also disproportionately employ women, blacks and immigrants, whereas export industries employ these workers to less than the average extent.

The comparisons in columns 4 and 5 of the characteristics of the industries employing typical export and import workers suggest all of the same qualitative conclusions as the more extreme comparisons of export and import intensive industries. Industry differences are attenuated because export and import intensive industries often coincide because of the importance of intraindustry trade. Nonetheless, the wage differential between the typical worker in import and export intensive industry is about 8 percent. 
These results suggest that for the United states, policies which succeed in promoting trade and increasing the volume of both exports and imports will tend to raise welfare, by moving workers from lower to higher wage industries. The gains are potentially significant. For example, the estimates here suggest that eliminating a manufacturing trade deficit of $\$ 150$ billion by raising exports rather than by reducing imports would increase labor rents by at least $\$ 12$ billion. If export intensive industries were expanded relative to import intensive industries, the gains could be up to three times as great.

\section{International Comparisons}

We have already documented that the wage structure is very similar in all countries. It follows that there is no way in which all countries can disproportionately export goods produced with high wage labor. A reasonable conjecture is that one concomitant of increased economic development is increased comparative advantage in the production of primary sector goods. To examine this possibility, Table 6 presents evidence on the American wage premium of import and export intensive industries for a numoer of countries, along with information on the American wage premium associated with the industries employing typical export and import workers.

The data provide initial support for our conjecture about patterns of economic development. Korea imports goods produced by high wage industries and exports goods produced by low wage industries. This is not simply a consequence of their abundance of 
Table 6: U..S. Log Wage Premia of Typical Import and Export Workers in Manufacturing in Nire Countries, 1983

\begin{tabular}{lccccc}
\hline Country & $\begin{array}{c}(1) \\
\text { Typical } \\
\text { Manuf } \\
\text { Worker }\end{array}$ & $\begin{array}{c}\text { Typical } \\
\text { Import } \\
\text { Worker }\end{array}$ & $\begin{array}{c}\text { Typical } \\
\text { Export } \\
\text { Worker }\end{array}$ & $\begin{array}{c}\text { (4) } \\
\text { Nop 108 } \\
\text { Worker }\end{array}$ & $\begin{array}{c}\text { (5) } \\
\text { Bottom 108 } \\
\text { Net Export } \\
\text { Worker }\end{array}$ \\
\hline Australia & .006 & .019 & .063 & .132 & .034 \\
Chile & -.024 & -.000 & .017 & .013 & .055 \\
France & .016 & .037 & .053 & .110 & .020 \\
Germany & .045 & .021 & .051 & .145 & -.106 \\
Japan & .002 & -.012 & .030 & .134 & -.113 \\
South Korea & -.039 & .020 & -.089 & -.216 & .077 \\
Sweden & & & & & \\
United States & .000 & -.004 & .033 & .051 & -.170 \\
\hline
\end{tabular}

Notes:

a. Three-digit ISIC US industry log wage premia weighted by each country's industry employment.

b. Three-digit ISIC US industry log wage premia weighted by each country's industry employment times $M / S$.

c. Three-digit ISIC US industry log wage premia weighted by each country's industry employment times $\mathrm{X} / \mathrm{S}$.

This table utilizes data from 18 ISIC manufacturing industries: $321,322,323$, $324,331,332,341,342,351,355,361,362,371,372,381,382,383,384$.

Sources: Trade flow data on an ISIC basis were provided by Robert Stern of the University of Michigan. The U.S. industry log wage premium variable

aggregates using employment weights the variable described in note (b) of

Table 4 from 3-digit Census industries to ISIC industries. Employment data are from the United Nations, Industrial Statistics Yearbook. 1984, volume 1, 1986. 
low skilled labor. The wage premia used in these comparisons are estimated controlling for measured labor quality, and the evidence cited in Section II suggests that they do not primarily reflect unobserved aspects of skill. Most of the developed countries appear to export relatively high wage premium goods while importing relatively low-wage goods. It is interesting that the difference in wage premiums between high and low net export industries is particularly pronounced in Germany and Japan.

The observation that specialization in high wage industries is correlated with per-capita income might be taken as evidence in favor of policies encouraging the growth of these industries. Such an inference would be premature, however. It seems plausible that improved technology, management, or worker skills would lead countries to shift towards capital intensive industries requiring investment in job specific human capital and highly motivated workers. Moving workers from low to high wage industries is likely to lead to increases in static allocative efficiency. Whether or not it would lead to increases in rates of growth is more problematic.

\section{Trends in American Trade}

Discussions of American competitiveness have differed on whether the changing trade patterns of recent years are simply the consequence of aberrant exchange rate movements brought about macroeconomic policies and speculative forces, or are instead the result of long term structural deterioration. A central issue in 
the deindustrialization debate is whether or not the United states has suffered particularly severe competitive losses in "good industries", variously defined as those that emphasize technology or have high value added per worker. The analysis in the preceding section suggests that examining the relative performance of high and low wage industries probably provides the best way of getting at this issue.

Assuming fixed ratios of employment to shipments, Table 7 indicates how changing trade patterns have affected employment in high and low wage industries. Between 1960 and 1980, the number of jobs displaced by imports was approximately equal to the number of jobs created by exports. Particularly during the 1970s, increased imports led to a reallocation of labor out of the lowest wage jobs in the manufacturing sector. Increased US exports led to increases employment in high wage sectors of the economy. During the 1980s, the fraction of workers employed in producing tradeable goods declined as the trade deficit increased. Between 1980 and 1984, the last year for which we have data available, the increase in the trade deficit was associated with a reduction of 1.4 million workers producing traded manufacturing goods. Over 600,000 or $43 \%$ of these workers worked in the quartile of industries that paid the lowest wages. This reflects the substantial increase in import penetration in industries like apparel during the early 1980s.

These results conflict dramatically with popular stereotypes suggesting that the United states is being forced away from cutting edge industries. We suspect that the popular misconception results 
Table 7: The Direct Impact of International Trade on Employment By Wage Class, U.S. Manufacturing 1960-84

Change in employment (in thousands) from ${ }^{a}$ :

Wage Premium Class ${ }^{b} \quad$ Imports Exports Net Exports

\section{Overall Manufacturing}

$\begin{array}{rrrr}1960-84 & -2621.3 & 1107.1 & -1514.2 \\ 1980-84 & -1248.0 & -168.4 & -1416.5 \\ 1970-80 & -941.5 & 946.7 & 5.2 \\ 1960-70 & -431.7 & 328.9 & -102.9\end{array}$

\section{Lowest Quartile}

$\begin{array}{rrrr}1960-84 & -1021.7 & 71.8 & -950.0 \\ 1980-84 & -576.2 & -60.7 & -636.9 \\ 1970-80 & -3 C 7.6 & 113.3 & -194.3 \\ 1960-70 & -138.0 & 19.2 & -118.8\end{array}$

Second Quartile

$1960-84$

$1980 \cdot 84$

$1970-80$

$1960-70$

Third Quartile

$$
\begin{array}{r}
-457.2 \\
-217.7 \\
-177.5 \\
-61.9
\end{array}
$$

323.0
10.1
242.8
70.1

$-134,1$

$-207.6$

65.3

8.2

$1960-84$

1980-84

$1970-80$

1960-70

$$
\begin{array}{r}
-547.8 \\
-220.5 \\
-229.9 \\
97.4
\end{array}
$$

271.5
-70.1
251.5
90.1

$-276.2$

$-290.6$

21.6

$-7.2$

Highest Quartile

$1960-84$
$1980-84$
$1970-80$
$1960-70$

$-594.7$

$-233.7$

$-226.6$

$-134.4$
440.8
$-47.6$
339.1
149.4

$-153.9$

$-281.3$

112.5

15.0

Notes:

'The loss in employment from imports for industry $i$ from period $t$ to $t$ ' is defined as $\left[\left(M_{i t},-M_{i t}\right) *(L / Q)_{i}\right]$ where $M$ is imports and $(L / Q)_{i}$ is the ratio of employment to output in industry 4 in 1984. Imports and output are measured in quantities with their nominal values deflated by the 4-digit SIC industry shipments deflator from the Annual Survey of Manufactures. The gain in employment from exports is analogously defined with exports replacing imports. The trade flow, employment, and output data is from the NBER TradeImmigration-Labor Market data set.

b Industries were ranked by the industry wage premium variable defined in note (b) of Table 4 and placed into quartiles based on 1983 employment. 
from the fact that traded goods industries as a whole pay higher wages than the rest of the economy. In a period when the trade deficit rises, good jobs are lost. But these jobs are likely to come back when the trade deficit returns to balance. 22 There appears to be little evidence through 1984 of relative deterioration in the high wage of portion of the American traded goods sector.

These patterns should not be surprising. Postulate that "cutting edge industries" pay wage premia. Following the discussion of Krugman and Baldwin (1987) assume that other nations are catching up with the United States. They then make incursions into the least progressive sectors of our economy, causing U.S. workers to move towards high wage industries.

\section{Conclusion}

The analysis in the preceding sections suggests that imperfections in the labor market may have at least as much significance as imperfections in product markets for trade policies. Labor market rents earned by workers in high-wage industries are very large relative to plausible estimates of monopoly profits. Unlike the case of product market imperfections where optimal policies are not robust to small changes in assumptions about corporate strategies, the theoretical case for policies which promote high wage premium industries is reasonably robust. Given that export industries in the United states have considerably higher

22 on the other hand, see Baldwin and Krugman (1986) for an argument that transitory exchange rate shocks may permanently affect an economy's ability to compete in some industries. 
wages than import competing industries even after controlling for observed worker skill measures, our theoretical arguments suggest that export promoting policies are much more likely to promote economic welfare than import competing policies.

There are of course a number of other considerations that must be weighed before any policy judgments are made. First, following much of the literature, we have abstracted from the possibility that some industries generate technological externalities. If such externalities are generated, and are limited by national boarders, there is a strong case for encouraging the growth of externality generating industries. Second, if wages are very sensitive to the rents earned by firms, it is possible that product market effects are more important than we have suggested but show up as labor market rents. Third, we have ignored input-output considerations in our discussion implicitly assuming that all output is produced in the industry making a given shipment. 23 Fourth, we have ignored political considerations that might lead activist policymakers to take steps that reduce rather than increase efficiency once the decision to undertake industrial policy was taken.

Despite these Iimitations, we believe that our results strengthen the economic case against import protecting policies and for export promoting policies. In future research, it would be useful to employ a general equilibrium model like those developed by

${ }^{23}$ Dickens and Lang (1988) find that taking into account inputoutput relations does not greatly affect one's conclusions concerning the cross-sectional relations among wage premiums and trade flows in the United states. 
Shoven and his collaborators to explore more precisely the impact of various policies in the presence of non-competitive wage differentials. Of particular interest would be a reevaluation of the 1986 Tax Reform Act which appears to have heavily burden the high-wage durable goods manufacturing sector of the economy. 


\section{References}

Akerlof, George A. "Gift Exchange and Efficiency Wages: Four Views." American Economic Review 74 (May 1984): 79-83.

Baldwin, Richard and Paul Krugman. "Persistent Trade Effects of Large Exchange Rate Shocks." NBER Working Paper No. 2017, September 1986.

Baldwin, Richard and Paul Krugman. "Industrial Policy and International Competition in Wide-Bodied Jet Aircraft." NBER, Mimeo, June 1987 (a).

Baldwin, Richard and Paul Krugman. "Modelling International Competition in High Technology Industries: Lessons from Aircrafts and Semiconductors." NBER Conference Paper, September 1987 (b).

Bhagwati, Jagdish N. and V.K. Ramaswami. "Domestic Distortions, Tariffs and the Theory of the Optimum Subsidy." Journal of Political Economy 71 (1963).

Bhagwati, Jagdish N. and T.N. Srinivasan, Lectures on International Trade. Cambridge, Ma.: MIT Press, 1983.

Brander, James A. and Barbara J. Spencer. "International R\&D Rivalry and Industrial Strategy." Review of Economic Studies 50 (1983): 70722 .

Brander, James A. and Barbara J. Spencer. "Tariff Protection and Imperfect Competition." In H. Kierzkowski, ed., Monopolistic Competition and International Trade. Oxford: Oxford University Press, 1984 .

Bulow, Jeremy and Lawrence H. Summers. "A Theory of Dual Labor Markets with Application to Industrial Policy, Discrimination, and Keynesian Unemployment." Journal of Labor Economics 4 (July 1986): 376-414.

Dickens, William T. and Lawrence F. Katz. "Inter-Industry Wage Differences and Industry characteristics." In $\mathrm{K}$. Lang and $\mathrm{J}$. Leonard, eds., Unemployment and the Structure of Labor Markets. Oxford: Basil Blackwell, 1987 (a).

Dickens, William T. and Lawrence F. Katz. "Inter-Industry Wage Differences and Theories of Wage Determination." NBER Working Paper No. 2271 , June 1987 (b).

Dickens, William T, and Lawrence F. Katz. "Further Notes on the Inter-Industry wage Structure." Mimeo, Harvard University, August 1988. 
Dickens, William $\mathrm{T}$. and Kevin Lang. "Why It Matters what we Trade." In L. Tyson, W.Dickens and J. Zysman, eds., The Dynamics of Trade and Employment. Cambridge, Ma.: Ballinger, 1988 .

Dixit, Avinash. "Optimal Trade and Industrial Policy for the U.S. Automobile Industry." In R. Feenstra, ed., Empirical Research in International Trade. Cambridge, Ma.: MIT Press, 1988.

Doeringer, Peter and Michael J. Piore. Internal Labor Markets and Manpower Analysis. Lexington, Ma.: D.C. Heath, 1971.

Freeman, Richard B. and Lawrence F. Katz. "Industrial Wage and Employment Determination in An Open Economy." Paper presented at NBER Conference on Immigration, Trade, and the Labor Market, September 1987 .

Gibbons, Robert S. and Lawrence F. Katz. "Learning, Mobility, and Inter-Industry Wage Differences." Mimeo, MIT, December 1987.

Hagen, E. "An Economic Justification for Protectionism." Quarterly Journal of Economics 62 (November 1958): 496-514.

Harberger, Arnold c. "On Measuring the Social opportunity cost of Labour." International Labour Review 103 (1971): 559-79.

Harris, J. and M. Todaro. "Migration, Unemployment and Development: A Two-Sector Analysis." American Economic Review 60 (March 1970): 126-43.

Holzer, Harry, Lawrence F. Katz, and Alan B. Krueger. "Job Queues and Wages: Some New Evidence on the Minimum Wage and Inter-Industry wage Structure." NBER Working Paper No. 2461, April 1988.

Katz, Lawrence F. "Efficiency Wage Theories: A Partial Evaluation." NBER Macroeconomics Annual 1 (1986); 235-76.

Krueger, Alan B. "Ownership, Agency, and Wages: An Empirical Analysis." Mimeo, Princeton University, 1987.

Krueger, Alan B. and Lawrence H. Summers. "Reflections on the InterIndustry Wage Structure," in $\mathrm{K}$. Lang and $\mathrm{J}$. Leonard, eds., Unemployment and the structure of Labor Markets. Oxford: Basil Blackwell, 1987.

Krueger, Alan B. and Lawrence H. Summers. "Efficiency Wages and the Inter-Industry Wage Structure." Econometrica 56 (March 1988): 25994.

Krugman, Paul. "The U.S. Response to Foreign Industrial Targeting." Brookings Papers on Economic Activity (1984:1): 77-121. 
Krugman, Paul. Strategic Trade Policy and the New International Economics. Cambridge: MIT Press, 1986.

Krugman, Paul. and Richard E. Baldwin. "The Persistence of the U.S. Trade Deficit." Brookings Papers on Economic Activity (1987:1): 144 .

Magee, S.P. International Trade and Distortions in Factor Markets. New York: Marcel Dekker, 1976.

Mars, Gerald. Cheats At Work. London: Unwin, 1982.

Mathewson, Stanley B. Restriction of Output Among Unorganized workers. Carbondale: Southern Illinois University Press, 1969.

Murphy, Kevin M. and Robert H. Topel. "Unemployment, Risk, and Earnings," In $\mathrm{K}$. Lang and J. Leonard, eds., Unemployment and the structure of Labor Markets. Oxford: Basil Blackwell, 1987.

Murphy, Kevin M. and Finis Welch. "The structure of Wages." Mimeo, Unicon Research Corporation, Los Angeles, February 1988.

Pencavel, John. An Analysis of the Quit Rate in American

Manufacturing. Princeton: Industrial Relations Section, 1970.

Sah, Raaj and Joseph E. Stiglitz. "THe Social Cost of Labor and Project Evaluation: A General Approach." Journal of Public Economics 28 (1985): 135-61.

Salinger, Michael A. "Tobin's Q, Unionization, and the Concentration-Profits Relationship." Rand Journal of Economics 15 (Summer 1984): 159-70.

Shapiro, Carl and Joseph E. Stiglitz. "Equilibrium Unemployment As A Worker Discipline Device." American Economic Review 74 (June 1984): 433-44.

Slichter, Sumner. "Notes on the structure of Wages." Review of Economics and statistics 32 (1950): 80-91.

Stiglitz, Joseph E. "Equilibrium Wage Distributions." Economic Journal 95 (September 1985): 595-618.

Stiglitz, Joseph E. "The Causes and Consequences of the Dependence of Quality on Price." Journal of Economic Literature 25 (March 1987) : $1-48$.

Weiss, Andrew. "Job Queues and Layoffs in Labor Markets with Flexible Wages." Journal of Political Economy 88 (June 1980): 52638. 